\title{
Viral contamination during sequential phacoemulsification surgeries in an experimental model
}

\section{Contaminação viral durante cirurgias sequenciais de facoemulsificação em um modelo experimental}

Roberto Pinto Coelho ${ }^{1}$, Tatiana Vannucci Garcia², Jayter Silva Paula², Antonio Augusto Velasco e Cruz ${ }^{3}$, Eduardo Melani Rocha², Luiz Tadeu Moraes Figueiredo ${ }^{4}$, Maria Lourdes Veronese Rodrigues ${ }^{3}$

\section{ABSTRACT}

Purpose: To determine the incidence of Piry virus contamination among surgical instruments used with disposable accessories for phacoemulsification during sequential surgeries

Methods: An experimental model was created with 4 pigs' eyes that were contaminated with Piry virus and 4 pigs' eyes that were not contaminated. Phacoemulsification was performed on the eyes, alternating between the contaminated and non-contaminated eyes. From one surgery to another, the operating fields, gloves, scalpel, tweezers, needles, syringes, tips and bag collector from the phacoemulsification machine were exchanged; only the hand piece and the irrigation and aspiration systems were maintained.

Results: In the collector bag, three samples from the contaminated eyes (3/4) were positive, and two samples from the non-contaminated (2/4) eyes were also positive; at the tip, one sample from the contaminated eyes (1/4) and two samples of the noncontaminated eyes (2/4) yielded positive results. In the irrigation system, one sample from a non-contaminated eye (1/4) was positive, and in the aspiration system, two samples from contaminated eyes (2/4) and two samples from non-contaminated eyes (2/4) were positive. In the gloves, the samples were positive in two samples from the non-contaminated eyes (2/4) and in two samples from the contaminated eyes (2/4). In the scalpel samples, three contaminated eyes (3/4) and none of the non-contaminated eyes (0/4) were positive; finally, two samples from the anterior chambers of the non-contaminated eyes gathered after surgery were positive.

Conclusions: In two non-contaminated eyes, the presence of genetic material was detected after phacoemulsification surgery, demonstrating that the transmission of the genetic material of the Piry virus occurred at some point during the surgery on these non-contaminated eyes when the hand piece and irrigation and aspiration systems were reused between surgeries.

Keywords: Phacoemulsification; Equipment reuse; Arboviruses; Equipment contamination

\section{RESUMO}

Objetivo: Determinar a incidência de contaminação com o vírus Piry entre os instrumentos cirúrgicos e acessórios usados durante cirurgias sequenciais de facoemulsificação. Métodos: Um modelo experimental foi realizado com quatro olhos de porcos que foram contaminados com o vírus Piry e quatro olhos de porcos não contaminados. A facoemulsificação foi realizada alternando um olho contaminado para outro olho não contaminado. Entre as cirurgias, os campos de operação, luvas, bisturi, pinças, agulhas, seringas, pontas e bolsa coletora foram trocados, mantendo somente a caneta e os sistemas de irrigação e aspiração do facoemulsificador.

Resultados: No saco coletor, três amostras de olhos contaminados (3/4) foram positivos, e duas amostras de olhos não contaminados (2/4) também foram positivos; na ponta do facoemulsificador, uma amostra dos olhos contaminados (1/4) e duas amostras de olhos não contaminados (2/4) apresentaram resultados positivos. No sistema de irrigação, uma amostra de um olho não contaminado (1/4) foi positivo, e no sistema de aspiração, duas amostras de olhos contaminados (2/4) e duas amostras de olhos não contaminados (2/4) foram positivos. Nas luvas, as amostras foram positivos em dois olhos não contaminados (2/4) e duas amostras de olhos contaminados (2/4). Nas amostras de bisturi, três olhos contaminados (3/4) e nenhum dos olhos não contaminados (0/4) foram positivose, finalmente, duas amostras da câmara anterior dos olhos não contaminados (2/4) reunidos após a cirurgia foram positivos.

Conclusões: Em dois olhos não contaminados, a presença de material genético foi detectado após a cirurgia de facoemulsificação, demonstrando que a transmissão do material genético do vírus Piry ocorreu em algum ponto durante a cirurgia para estes olhos não contaminados, quando a caneta de facoemulsificação e o sistema de irrigação e aspiração foram reutilizados entre as cirurgias.

Descritores: Facoemulsificação; Reutilização de equipamento;Arbovírus; Contaminação de equipamentos

\section{INTRODUCTION}

Adherence to manufacturers' recommendations for the single use of phacoemulsification accessories has been the standard practice. Therefore, in developing countries, with the increasing quantity of phacoemulsification procedures performed, there has been a corresponding increase in the number of disposable phaco accessories that have been purchased and used. This increase has occurred si- multaneously with the implementation of cost-reduction initiatives precipitated by increased demand, which have caused increases in supply costs to undergo close scrutiny.

Although routine procedures enable maximum sterility, a significant source of contamination may be the internal tubing of automated surgical equipment contiguous to the operating field and in aqueous communication with the patient's eye, which effectively
Submitted for publication: October 25, 2011

Accepted for publication: March 11, 2012

Study carried out at Department of Ophthalmology and Otorhinolaryngology, Faculdade de Medicina de Ribeirão Preto - USP - Ribeirão Preto.

Physician, Cataract Service, Department of Ophthalmology and Otorhinolaryngology, Faculdade de Medicina, Universidade de São Paulo - USP - Ribeirão Preto (SP), Brazil.

Physician, Department of Ophthalmology and Otorinolaryngology, Faculdade de Medicina, Universidan, Department of Ophthalmology and Otorhinolaryngology, Faculdade de Medicina, Universidade de São Paulo - USP - Ribeirão Preto (SP), Brazil.

Professor, Department of Ophthalmology and Otorhinolaryngology Faculdade de Medicina, Universidade de São Paulo - USP - Ribeirão Preto (SP), Brazil.

Professor, Virology Department, Faculdade de Medicina, Universidade de São Paulo - USP - Ribeirão Preto (SP), Brazil.
Funding: No specific financial support was available for this study.

Disclosure of potential conflicts of interest: R.P.Coelho, None; T.V.Garcia, None; J.S.Paula, None; A.A.V. e Cruz, None; E.M.Rocha, None; L.T.M.Figueiredo, None; M.L.V.Rodrigues, None.

Correspondence address: Roberto Pinto Coelho. Departamento de Oftalmologia, Otorrinolaringologia e Cirurgia de Cabeça e Pescoço, Hospital das Clínicas de Ribeirão Preto - Universidade de São Paulo. Av. Bandeirantes, 3900 - Ribeirão Preto (SP) - 14049-900 - Brazil

E-mail: robertopintocoelho@uol.com.br 
contaminates the aspiration fluid ${ }^{(1-3)}$. Contamination of the aspiration fluid may seem normal to a certain extent because it has been shown that during and at the conclusion of intraocular operations, bacteria are present on the conjunctiva and in the anterior chamber $r^{(4,5)}$.

It has been suspected that reflux from the internal tubing represented a potential source of endophthalmitis, but outflow lines have not been investigated. Therefore, the significance of this finding has remained unclear. Recently, contamination of the internal tubing has also been confirmed in vitrectomy machines ${ }^{(6)}$.

In this study, we hypothesized that disposable phaco accessories used in cataract surgery can be a vector of transmission of infectious systemic and ocular diseases caused by various microorganisms, such as viruses, bacteria and prions, when a part of the accessory is not exchanged between phaco surgeries.

\section{METHODS}

This study was previously approved by the local University Hospital Ethics Committee/Institutional Review Board. To assess possible instrument contamination and transmission to subsequent eyes, we performed ocular inoculation with the Piry virus, which is easily cultured in the laboratory and demonstrates extremely high multiplication rates and low infectivity and pathogenicity for humans.

The seed stock of the Piry virus, strain BeAn $41191\left(\operatorname{LD}_{50}=10^{8,5}\right)$, was obtained from the brain macerates of an infected mice.

Each pig eye was inoculated with 107.36 LD 50 of Piry virus $(23,000,000$ virus particles dose lethal to $50 \%$ of the mice used to quantitate the virus), contained in $300 \mu \mathrm{L}$. This volume of viral solution, diluted 1:10 was injected into one enucleated pig eye by corneal paracentesis with an insulin syringe (Figure 1).

The experimental model was established in 4 pigs' eyes that were contaminated and in 4 pigs' eyes that were not contaminated. The contaminated eyes were identified as C2, C3, C4 and C5. Another pig's eye (C1) was inoculated with $300 \mu \mathrm{L}$ of diluted MEM; that eye was used as a negative control for the experiments (Figure 1). The non-contaminated eyes were identified as N1, N2, N3, N4 and N5. The phacoemulsification was performed using a Universal Model II ${ }^{\circledR}$ phaco system (Alcon Laboratories) and was performed by alternating between contaminated and non-contaminated eyes.

After each surgery, surgical drapes and the operated eye were removed; the tip, the bag used to collect the phaco fluids and all of the instruments used during surgery (e.g., forceps, needles, syringes, gloves and $2.75 \mathrm{~mm}$ scalpels) were exchanged. The new eye to be operated upon was placed in the new operative field, and only the handpiece used for phacoemulsification, without the tip, and the irrigation and aspiration tubing remained.

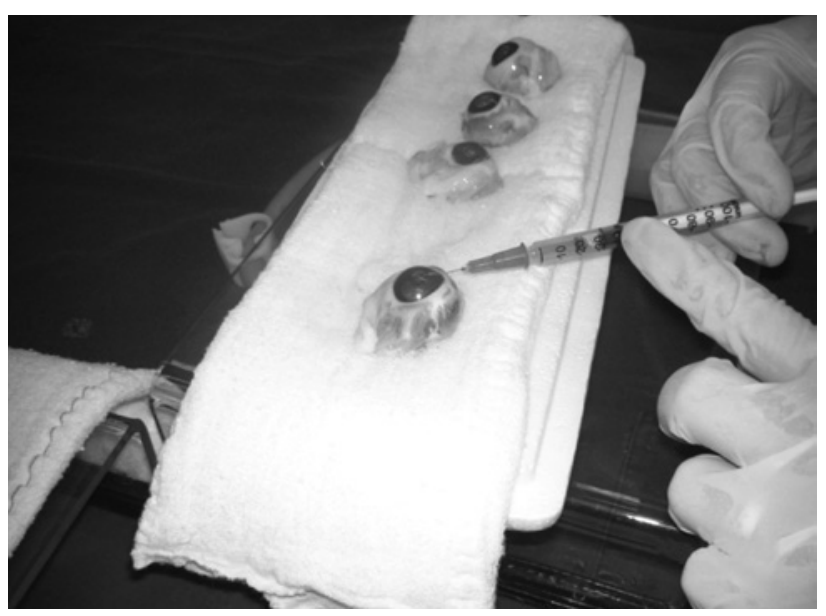

Figure 1. Contamination of pig eyes.
Seven sites were sampled for virus assessment: the anterior chamber, phacoemulsification tip, irrigation tubing, aspiration tubing, scalpel (2.75 mm), bag collector and gloves (Figure 2). The samples were washed and/or aspirated with approximately $0.5 \mathrm{~mL}$ of saline solution ( $\mathrm{NaCl} 0.9 \%$ ) connected to a $5 \mathrm{~mL}$ syringe and stored in an Eppendorf tube. These samples were taken from the collection, preserved in ice and, finally, stored in a freezer at $-70{ }^{\circ} \mathrm{C}$ until the reactions were processed.

For the detection of viral RNA, RNA was initially extracted from the samples using the RTP ${ }^{\circledR}$ DNA/RNA Virus Mini Kit (INVITEK, Germany), the product of which was filtered from the centrifuged samples. Reverse transcription, which generates complementary DNA from the viral genomic RNA that is then amplified by primers for PCR (nested RT-PCR), was used to amplify part of the G glycoprotein gene of the Piry virus and to produce amplification products (amplicons). Amplicons obtained from the nested-PCR were visualized on $2.0 \%$ agarose gel, loaded with the sample and 2-5 $\mu \mathrm{L}$ of dye. The gels were electrophoresed at 100 volts and were then treated with a solution containing $0.5 \mathrm{mg} / \mathrm{ml}$ ethidium bromide, washed with water and observed under ultraviolet (UV) light.

\section{RESULTS}

\section{SAMPLES from the ANTERIOR CHAMber before PHACOEMULSIFICATION}

It was possible to detect the presence of amplicons in all of the eyes (4/4) infected by the Piry virus, but none of the non-contaminated eyes.

\section{SAmples from the COLLector bag}

Among the samples collected from the collector bag after the surgeries, it was possible to detect the presence of amplicons in three (3/4) of the contaminated eyes and two (2/4) of the non-contaminated eyes.

\section{SAMPLES FROM THE TIP}

It was possible to detect the presence of amplicons in the tip of one (1/4) sample from the contaminated eyes subjected to surgery. Among the non-contaminated eyes, it was possible to detect the presence of amplicons in two (2/4) samples.

Samples from the Irrigation Tubing - It was possible to detect the presence of amplicons in none (0/4) of the contaminated eyes and in one (1/4) sample from the non-contaminated eyes.

\section{SAMPLeS From the ASPIRATION TUBING}

It was possible to detect the presence of amplicons in samples from two (2/4) contaminated eyes and two (2/4) non-contaminated eyes.

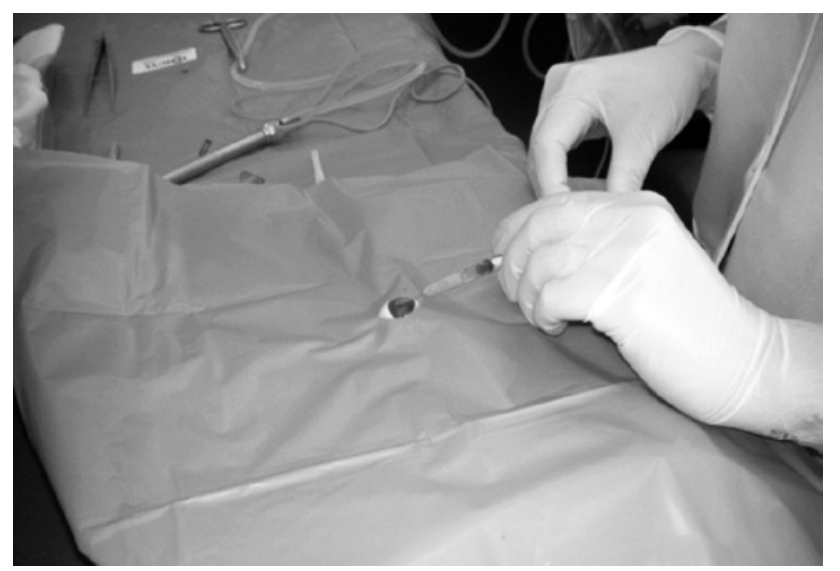

Figure 2. Collection of material from the anterior chamber. 
Table 1. Summarizes the results in the contaminated eyes and non-contaminated eyes. Detection of amplicons of $\sim 130 \mathrm{bp}$ at the site collected

\begin{tabular}{|c|c|c|c|c|c|c|c|c|c|c|c|}
\hline & & C1 & N1 & $\mathbf{C 2}$ & N2 & C3 & N3 & C4 & N4 & C5 & N5 \\
\hline I & Anterior chamber before phaco & - & - & + & - & + & - & + & - & + & - \\
\hline$\|$ & Collector bag & - & - & - & - & + & + & + & - & + & + \\
\hline III & Tip & - & - & - & - & - & + & - & - & + & + \\
\hline IV & Irrigation tubing & - & - & - & + & - & - & - & - & - & - \\
\hline V & Aspiration tubing & - & - & - & + & + & + & - & - & + & - \\
\hline VI & Glove & - & - & - & + & + & + & + & - & - & - \\
\hline VII & 2.75-mm scalpel & - & - & + & - & + & - & - & - & + & - \\
\hline VIII & Anterior chamber after phaco & $n$ & - & $\mathrm{N}$ & - & $\mathrm{n}$ & + & $\mathrm{n}$ & + & $n$ & - \\
\hline
\end{tabular}

\section{SAMPLes From the GLOVE}

It was possible to detect the presence of amplicons in two (2/4) samples that were from contaminated eyes and in two (2/4) samples from non-infected eyes.

\section{SAMPLES From the 2.75 MM SCALPEL}

Three (3/4) samples from the scalpels used on infected eyes and no samples (0/4) from the scalpels used on uncontaminated eyes revealed the presence of amplicons.

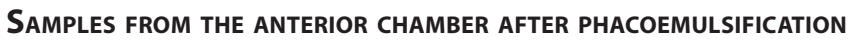

After the surgeries, no (0/4) samples obtained from the anterior chambers of contaminated eyes subjected to phacoemulsification were positive. Amplicons were detected by RT-nested PCR in two (2/4) of the four non-contaminated eyes.

The results of presence amplicons at sites sampled for virus assessment in the contaminated eyes and the non-contaminated eyes were summarized in table 1.

\section{DISCUSSION}

Bacterial and fungal contamination of the automated surgical equipment used during routine cataract surgery has been reported $^{(7,8)}$. Investigations have shown that residual debris in reused phacoemulsification probes can be a potential source of post-phacoemulsification endophthalmitis ${ }^{(9-11)}$.

Viral contamination may be associated with the reuse of automated surgical equipment during cataract surgery. This association is particularly true for the risk associated with ophthalmic surgery and even more so in the case of cataract surgery, a procedure mostly performed in elderly patients who have very high rates of HCV infection ${ }^{(12-14)}$. An association between HCV infection and ophthalmic surgery, mostly performed for cataracts, has been reported ${ }^{(15)}$. Additionally, different types of viral contamination after corneal transplantation have been reported, including the rabies virus ${ }^{(16)}$, prion Creutzfeldt-Jakob disease (CJD) ${ }^{(17)}$, hepatitis $B^{(18)}$ and the acquired immunodeficiency virus ${ }^{(19)}$. Notably, HIV-RNA was detected in the aqueous humor and subretinal fluid of an HIV carrier with a rhegmatogenous retinal detachment ${ }^{(20)}$.

Factors are possibly involved as well, including skilled surgeons performing cataract surgery in only a few minutes, the high demand for surgeries ${ }^{(21)}$ (especially in the public health system), the low price paid for surgery in the government health system, the high cost of cassettes (many of which suffer structural damage when uncoupled from the phaco, preventing their re-sterilization), and only a small number of hospitals having fast sterilization machines, thus creating a delay in the sterilization process. Additionally, some surgeons may even use the same tape irrigation and aspiration for many surgeries in one day, changing only the handpiece or exchanging only the tip, and using the same tape and pen for multiple surgeries.

In this context, we created an experimental model using pig eyes artificially contaminated with a virus for comparison with uncontaminated eyes. We chose the Piry vesiculovirus because it is easily grown in a laboratory, its replication is fast and it easily produces a large number of copies.

The first two eyes ( $\mathrm{C} 1$ and $\mathrm{N} 1$ ) were set aside as negative controls, and no positive results were found in any of their samples, as expected. Of the samples from the anterior chambers of contaminated eyes before surgery $(C 2, C 3, C 4, C 5)$, all of them showed positive results; of the samples from non-contaminated eyes (N2, N3, N4, N5), none of them showed positive results, demonstrating that contamination was efficient and that there were no false-positive results.

The detection of amplicons in the bag collector after surgery on two uncontaminated eyes (eye samples N3 and N5) and in two samples from tips used on uncontaminated eyes (eye samples N3 and N5) corroborates the possibility that viral particles were retained somewhere in the phacoemulsifier and that the routes could have been the internal irrigation or aspiration pen or even the methods of irrigation and aspiration.

Among the samples from the irrigation route, positive results were observed in one eye (N2), as the means of irrigation brought the flow of fluid into the eye; this result could only be positive if there was a reflux of fluid during the procedure or if there was contamination during the handling of the equipment. In the samples from gloves, we obtained two positive contaminated eyes (C3 and (4) and two positive non-contaminated eyes (N2 and N3), and we believe that while manipulating the pen, it was contaminated with another sterile glove, so there was transfer of viral genetic material to this glove, which was expected.

Thus, we observed that all of the components of phacoemulsifier (tip, roads, irrigation and aspiration, collector bag) and the instruments connected to it, such as the knife and glove, became infected after one or more surgery.

\section{CONCLUSION}

Considering the large proportion of the general population undergoing surgery or other invasive procedures, the present results stress the importance of complying with universal precautions and implementing efficient maintenance and sterilization methods for medical instruments. Ideally, disposable materials should be used with care, particularly during phacoemulsification, because of the increased risk of infection due to the high turnover of patients. 


\section{REFERENCES}

1. Kattan HM, Flynn HW Jr, Pflugfelder SC, Forster RK. Nosocomial endophthalmitis survey. Current incidence of infection after intraocular surgery. Ophthalmology. 1991; 98(2):227-38.

2. Pflugfelder SC, Flynn HW Jr. Infectious endophthalmitis. Infect Dis Clin North Am 1992;6(4):859-73.

3. O'Brien TP, Green WR. Endophthalmitis. In: Mandell GL, Bennett JE, Dolin R, editors Mandell, Douglas and Bennett's Principles and practice of infectious disease. $4^{\text {th }}$ ed New York: Churchill Livingstone; 1995. p.1120-9.

4. Ariyasu RG, Nakamura T, Trousdale MD, Smith RE. Intraoperative bacterial contamination of the aqueous humor. Ophthalmic Surg. 1993;24(6):367-73; discussion 373-4.

5. Mistlberger A, Ruckhofer J, Raithel E, Muller M, Alzner E, Egger SF, et al. Anterior chamber contamination during cataract surgery with intraocular lens implantation. J Cataract Refract Surg. 1997;23(7):1064-9. Comment in: J Cataract Refract Surg. 2003; 29(8):1465-6; author reply 1446

6. Janknecht $\mathrm{P}$, Kappstein I. Bacterial contamination of the pressure receiver of a vitrec tomy machine. Ophthalmic Surg Lasers. 1997;29(4):345-7.

7. Mino de Kaspar H, Grasbon T, Kampik A. Automated surgical requires routine disinfection of vacuum control manifold to prevent postoperative endophthalmitis Ophthalmology. 2000;107(4):685-90. Comment in: Ophthalmology. 2001;108(4):636-7.

8. Kappstein I, Schneider CM, Grundmann H, Scholz R, Janknecht P. Long-lasting contamination of a vitrectomy apparatus with Serratia marcescens. Infect Control Hosp Epidemiol. 1999;20(3):192-5.

9. Leslie T, Aitken DA, Barrie T, Kirkness CM. Residual debris as a potential cause of post phacoemulsification endophthalmitis.Eye (Lond). 2003;17(4):506-12.

10. Baskaran M, Rao SK, Ramana Kumar PJ, Vijaya L, Madhavan HN. Postphacoemulsification endophthalmitis-role of residual debris in the handsets used for surgery. Eye (Lond.) 2004;19(1):115-6. Comment on: Eye (Lond). 2003;17(4):506-12.

11. Rao SK, Baskaran M, Kumar PJ, Vijaya L, Madhavan HN. Debris in phacoemulsification handsets. A potential cause of endophthalmitis after cataract surgery? Ind J Ophthalmol.
2004;52(1):80-1. Comment in: Indian J Ophthalmol. 2004;52(3):260-1; author reply 261-2

12. Bellentani S, Tiribelli C, Saccoccio G, Sodde M, Fratti N, De Martin C, et al. Prevalence of chronic liver disease in the general population of northern Italy: the Dionysos study. Hepatology. 1994;20(6):1442-9.

13. Stroffolini T, Menichelli M, Taliani G, Dambruoso V, Poliandri G, Bozza A, et al. High prevalence of hepatitis $C$ virus infection in a small central Italian town: lack of evidence of parenteral exposure. Ital J Gastroenterol. 1995:27(5):235-8.

14. Guadagnino V, Stroffolini T, Rapicetta M, Costantino A, Kondili LA, Menniti Ippolito F, et al. Prevalence, risk factors and genotype distribution of hepatitis $C$ virus infection in the general population: a community-based survey in southern Italy. Hepatology. 1997;26(4):1006-11.

15. Mele A, Spada E, Sagliocca L, Ragni P, Tosti M, Gallo G, et al. Risk of parenterally transmitted hepatitis following exposure to surgery or other invasive procedures: results from the hepatitis surveillance system in Italy. Hepatology. 2001;35(2):284-9.

16. Houff S, Burton R, Wilson R, Henson T, London WT, Baer GM, et al. Human-to-human transmission of rabies virus by corneal transplant. N Engl J Med. 1979;300(11):603-4.

17. Lang CJ, Heckmann JG, Neundorfer B. Creutzfeldt-Jakob disease via dural and corneal transplants. J Neurol Sci. 1998;160(2):128-39.

18. Hoft R, Pflugfelder S, Foster R, Ullman S, Polack FM, Schiff ER. Clinical evidence for hepatitis B transmission resulting from corneal transplantation. Cornea. 1997;16(2): 132-7.

19. Schwarz A, Hoffmann F, Lage-Stehr J, Teqzess Am, Offermann G. Human immunodeficiency virus transmission by organ donation. Outcome in cornea and kidney recipients. Transplantation. 1987;44(1):21-4.

20. Kashiwagi K, Gohdo T, Sato S, lijima H, Tsukahara S. Detection of HIV-RNA in aqueous humor and subretinal fluid in an HIV carrier with rhegmatogenous retinal detachment. Jpn J Ophthalmol. 2000;44(6):687-9.

21. Centers for Disease Control. Update: universal precautions for prevention of transmission of human immunodeficiency virus, hepatitis B virus, and other bloodborne pathogens in health-care settings. MMWR Morb Mortal Wkly Rep. 1988; 37(24):377-82, 387-8.

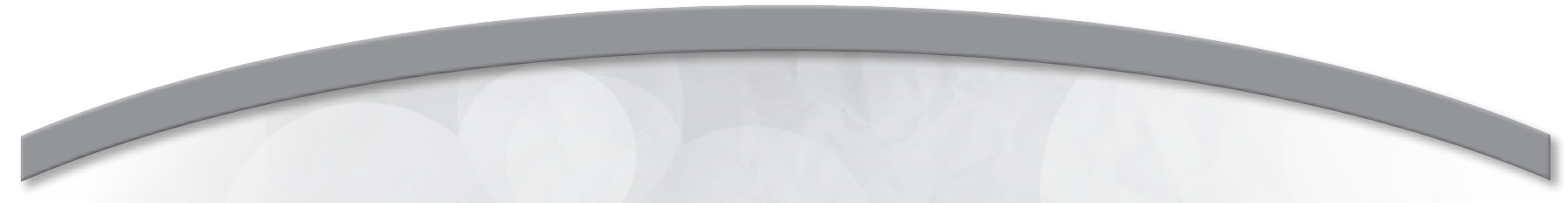

VI Congreso Latinoamericano de Glaucoma

\section{5 e 6 de outubro de 2012}

Santiago - Chile

Informações:

E-mail: dgrigera2@fibertel.com.ar

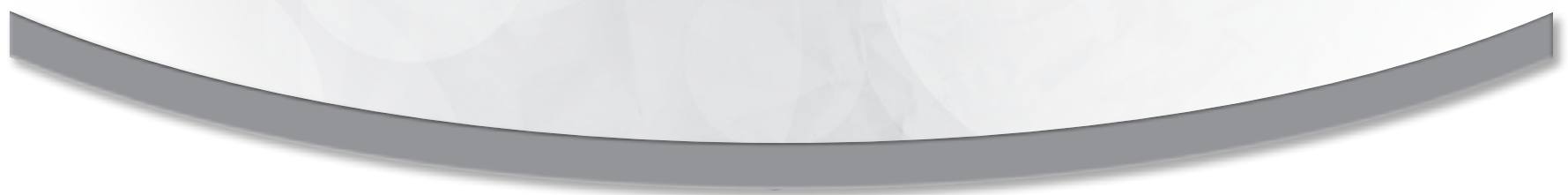

